\title{
A CONSTRUÇÃO DA PERSONAGEM ASLAN E SUAS RELAÇÕES COM O UNIVERSO CRISTÃO EM LÍNGUA INGLESA E EM LÍNGUA PORTUGUESA: UM ESTUDO BASEADO NO CORPUS DA OBRA DE C. S. LEWIS
}

\author{
Talita Serpa \\ Univeridade Estadual Paulista \\ São José do Rio Preto, SP \\ Celso Fernando Rocha ${ }^{* *}$ \\ Univeridade Estadual Paulista \\ São José do Rio Preto, SP \\ Vanessa Prestes Soares ${ }^{* * *}$ \\ SESI- Departamento Regional do Estado do Paraná
}

\section{Resumo}

Este trabalho tem por objetivo analisar a construção da personagem Aslan, na crônica The Lion, the Witch and the Wardrobe (1994), escrita por C. S. Lewis, e na respectiva tradução, realizada por Mendes Campos (2002). Para isso, consideramos a intertextualidade entre tal estória e a narrativa da Bíblia Sagrada (1994), focando-nos, principalmente, nas construções léxico-contextuais que tangem a personagem-objeto de nosso estudo. Para isso, guiamo-nos por pressupostos dos estudos da área da Lexico-logia (BARBOSA, 1990, 1998; DUBOIS, 2001), da Linguística de Cor-pus (BERBER SARDINHA, 2000, 2002) e dos Estudos da Tradução Ba-seados em Corpus (BAKER, 1999, 2000; CAMARGO, 2005, 2007), bem como nos valemos dos subsídios disponibilizados pelas ferramentas do programa WordSmith Tools (WordList e Concord), a fim de verificarmos qual o comportamento tradutório adotado mediante uma obra rica em significações e relevante dentro do panorama literário mundial. Notamos, com base em nosso levantamento das palavras de maior frequência em contexto, que os textos fonte e meta apresentam aproximações no que diz respeito às escolhas lexicais para a composição intertextual bíblica, crian-do imagens associativas entre Aslan e Cristo.

Palavras-chave: Aslan. Intertextualidade. Cristianismo. Tradução. Estudos da Tradução Baseados em Corpus.

\footnotetext{
*Doutoranda pelo programa de Estudos Linguísticos da Unesp - São José do Rio Preto e Profa. Me. da União das Faculdades dos Grandes Lagos. Seu e-mail é talitasrp82@gmail.com

** Doutor em Lingüística Aplicada pela Universidade Estadual Paulista Júlio de Mesquita Filho (2010) e graduação em Bacharelado em Letras Tradução (inglês/espanhol) pela Universidade Estadual Paulista Júlio de Mesquita Filho (2004). Atualmente é Professor Efetivo da Unesp - São José do Rio Preto. Seu e-mail é celso@ ibilce.unesp.br

${ }^{* * *}$ Graduada em Letras - Português e Inglês pela União das Faculdades dos Grandes Lagos (2013). Atualmente é professora da SESI - Departamento Regional do Estado do Paraná. Seu e-mail é van_psoa@hotmail.com
} 
THE CONSTRUCTION OF THE CHARACTER ASLAN AND HIS RELATIONS

WITH THE CHRISTIAN UNIVERSE IN ENGLISH AND PORTUGUESE: A STUDY BASED ON THE CORPUS OF C.S.LEWIS WORK Abstract

The main purpose of this article is to analyze the construction of the character Aslan in the chronicle The Lion, the Witch and the Wardrobe (1994) written by C. S. Lewis and in its translation into Portuguese by Mendes Campos (2002). We took into consideration the intertextuality presented between the story and the Holy Bible (1994 [Portuguese version]), focusing, mainly, on lexical and contextual constructions in relation to the target-character under investigation. Lexicology (BARBOSA, 1990, 1998; DUBOIS, 2001), Corpus Linguistics (BERBER SARDINHA, 2000, 2002) and Corpus-based translation studies were applied as theoretical background (BAKER, 1999, 2000; CAMARGO, $2005,2007)$. We also employed subsidies provided by the software suite WordSmith Tools (Wordlist and Concord) in order to observe the translation procedures adopted to convey into Portuguese a that is relevant work, in the international literary scenario and that abounds symbolic meaning. The results, based on the most frequent words in context, show that both the target and source text present similitudes in terms of words selected to establish intertextual relations with the Bible, crafting associative images between Aslan and Christ.

Keywords: Aslan. Intertextuality. Christianism. Translation. Corpus-based Translation Studies. 


\section{Introdução}

A obra As Crônicas de Nárnia (1950-1956) sempre foi objeto de interesse de pesquisadores nas áreas mais diversas da Literatura, da Linguística e mesmo da Tradução, dada sua constituição narrativa e a inter-relação de sentidos com os demais textos e produções do autor C. S. Lewis, o qual ganhou destaque, principalmente, por suas conferências para a British Broadcasting Corporation (BBC), intituladas Cristianismo Puro e Simples (1941-1947[1992]).

Profundo conhecedor das Letras e da Literatura, bem como de Teologia e Linguística, Lewis foi professor de Literatura Medieval e Renascentista na Universidade de Cambridge, onde, por volta da década de 50, passou a se dedicar à escrita daquela que seria "sua maior realização" (BROWN, 2005, p. 17).

A história, sobre um "reino" mágico e lendário, em que várias mitologias, a princípio dissociadas, dialogam de maneira magistral, compõe um compêndio de sete pequenas crônicas, a saber: O leão, a feiticeira e o guarda-roupa; Príncipe Caspian; A viagem do peregrino da alvorada; A cadeira de prata; $O$ cavalo e seu menino; O sobrinho do mago e A última batalha.

Em tais historietas, segundo autores como Arruda (2016), Duarte (2015), Gonçalves (2015) e Lira (2011), Lewis traça um paralelo intertextual com narrações e personagens bíblicas, levando em conta seu profundo conhecimento sobre o Cristianismo e atrelando seus heróis e protagonistas a papéis marcados por caracterizações religiosas.

Sendo assim, em nosso trabalho, focamos a composição da personagem Aslan, assim como a sua relação com os preceitos cristãos, na obra The Lion, the Witch and the Wardrobe (1994), de C. S. Lewis e na respectiva tradução para a língua portuguesa, realizada por Mendes Campos (2002). Tencionamos discutir possíveis aproximações e distanciamentos no que tange aos moralismos e ensi-namentos sagrados concernentes à sociedade da época e aos dizeres religiosos do autor. Observamos, ainda, a inter-relação semântica da construção dos textos fonte (TF) e meta (TM), principalmente partindo do pressuposto de que "o Leão" representa não somente a força e o poder, mas também suas implicações na cons-trução do conceito de "divindade" implícito na obra.

Procedemos uma investigação acerca da composição intertextual ${ }^{1}$ que cir-cunscreve o principal personagem da narrativa, selecionando os vocábulos con-cernentes ao nome Aslan e a sua representação física na forma felina. Também procuramos salientar outras palavras do Universo de Nárnia, as quais, em decor-rência de sua ampla frequência de utilização, podem ser utilizadas para compor a descrição e o aprofundamento das características da personagem. Para tanto, nos valemos de duas das ferramentas disponibilizadas pelo programa WordSmith Tools (versão 6.0), a saber: WorldList e Concord.

Tecermos, assim, a relação entre Linguística de Corpus, Estudos da Tradu-ção Baseados em Corpus, Lexicologia, Literatura e Tradução, e nos baseamos nos trabalhos de estudiosos: Berber Sardinha (2000), Baker (1999, 2000), Barbo-sa (1990, 1998), Dubouis (2001), Gonçalves (2007), Leite (1985), Brown (2005), 
Camargo (2007), Magalhães Filho (2005), Greggersen (2010) e Zyngier, Viana e Jandre (2007a), Zyngier, Viana e Silveira (2007b), Zyngier (2011).

Desse modo, promovemos a discussão de questões pertinentes, principalmente, a relação entre trechos da constituição narrativa da personagem e seu envolvimento com valores cristianizados, os quais consideramos presentes de maneira recorrente na composição da obra como um todo, mas com foco maior na correlação entre Aslan e Cristo.

Salientamos que o trabalho com corpora, associado aos procedimentos interpretativos promovidos pela fortuna crítica da obra, permite a possibilidade de elencar os itens léxico-semânticos que auxiliam na formulação da simbologia de elementos apontados pelo discurso bíblico ${ }^{2}$.

\section{Breve caracterização das personagens em Nárnia: intertextualidade na composição de Aslan}

Entre os principais personagens da crônica estão: Aslam (Aslan, no original), Lúcia, Susana, Pedro e Edmundo Penvensie, Jadis (a feiticeira) e o Sr. Tumnus (o fauno). Focamos, em nossa investigação, o "Leão", o filho do Imperador Além-Mar. O grande criador da terra de Nárnia, com seu canto, o único que pode quebrar o feitiço da bruxa e salvar o reino de seu cruel e eterno inverno. Visto com "temor" e grande "respeito", Aslan tem sua volta esperada com extremo anseio.

Levando em consideração a carga de significação associada à personagem, bem como as experiências de vida do autor com o Cristianismo, torna-se possível à fortuna crítica estabelecer relações de sentido entre as aventuras na terra mágica com a narrativa bíblica. Magalhães Filho (2005), por exemplo, autor do livro O imaginário em as Crônicas de Nárnia, expressa a ideia geral que permeia o fantástico nas estórias de Lewis: "Com a ajuda do Leão Aslan (uma imagem de Cristo, de Redentor), o Bem sempre triunfa sobre o Mal” (2005, p. 50). Tal afir-mação fica explícita no seguinte trecho:

- E se ela transformar também ele numa estátua de pedra? - perguntou Edmundo.

- Deixe com ele, Filho de Adão. Não é tão fácil assim! - respondeu o Sr. Castor, caindo na gargalhada. - Transformar ASLAM em pedra? Se ela conseguir manter-se em pé diante dele, olhá-lo cara a cara, já é caso para dar-lhe os parabéns. Não, não. Ele vem botar tudo nos eixos. Assim diz um velho poema que costumamos cantar:

O mal será bem quando Aslam chegar,

Ao seu rugido, a dor fugirá,

Nos seus dentes, o inverno morrerá,

Na sua juba, a flor há de voltar. (LEWIS, 1994, p.96, grifo do autor)

Nessa passagem vemos que há uma profecia sobre a vinda (ou volta) de Aslan e que esse evento será marcado pelo fim da maldição, ou seja, do inverno e do governo tirano da feiticeira. Paralelamente, tanto a vinda de Cristo ao mundo 
quanto sua volta para buscar a igreja são previstas por profecias em diversos livros das Escrituras:

E disse-me um dos anciãos: Não chores; eis aqui o Leão da tribo de Judá, a raiz de Davi, que venceu, para abrir o livro e desatar os seus sete selos (BÍBLIA, Apocalipse, 5, 5).

E naquele dia se dirá: Eis que este é o nosso Deus, a quem aguardávamos, e ele nos salvará; este é o Senhor, a quem aguardávamos; na sua salvação gozaremos e nos alegraremos (BÍBLIA, Isaías, 25, 9).

Eis que o Senhor DEUS virá com poder (BÍBLIA, Isaías, 40, 10).

Podemos, por conseguinte, constatar que esta é uma das primeiras e principais similaridades: ambos os textos se referem ao aparecimento de um ser divino que, de alguma forma, trará paz e vencerá o mal.

\section{Fundamentação teórica}

Considerando que esta pesquisa se propôs a analisar as escolhas que foram feitas no ato tradutório, no que concerne à descrição das aparições da personagem Aslan, o presente trabalho foi baseado nos estudos de corpus, que nos permitem ter acesso a um levantamento léxico-semântico que serve de subsídio para as considerações aqui almejadas.

\subsection{Os conceitos de palavra e vocábulo}

Os conceitos utilizados em nossa investigação são descritos no Dicionário de Linguística (DUBOIS, et. al. 2001, p.449-450), encabeçado por Jean Dubois, como, palavra

(...) um elemento linguístico significativo composto de um ou mais fonemas; essa sequência é suscetível de uma transcrição escrita (ideogramática, silabaria ou alfabética) compreendida entre dois espaços em branco; ela conserva sua forma, total ou parcialmente (no caso da flexão), em seus diversos empregos sintagmáticos; a palavra denota um objeto (substantivo), uma ação ou um estado (verbo), uma qualidade (adjetivo), uma relação (preposição), etc.

Além dessa leitura, as palavras relacionam-se com os vocábulos, que são descritos como:

(...) a ocorrência de um lexema no discurso, na terminologia da estatística lexical. Como o termo lexema está reservado às unidades (virtuais) que compõem o léxico, o termo palavra a qualquer ocorrência realizada em fala, o vocábulo será a atualização de um lexema particular no discurso. Sob este ponto de vista, o lexema é uma unidade do léxico (estoque potencial do indivíduo ou da língua), enquanto o vocábulo e a palavra são unidades do vocabulário (unidades efetivamente empregadas num determinado uso de 
comunicação); a palavra representa então toda unidade emitida (...) enquanto o vocábulo representa uma unidade particular emitida considerada em refer-ência ao léxico. (DUBOIS, et. al. 2001, p.614)

Nas teorizações de Barbosa $(1990,1998)$, as palavras são plurifuncionais, e a determinação de sua funcionalidade depende de sua inserção em uma discursividade. Assim sendo, há uma disponibilização da funcionalidade para as unidades lexicais em um texto-ocorrência, de forma que se constitui uma dinâmica interuniversos permitindo a circulação das palavras entre língua e contextos.

\subsection{Linguística de Corpus e Estudos da Tradução Baseados em Corpus}

A Linguística de Corpus, como define Berber Sardinha (2000, p. 325), é a ciência que estuda os dados da língua, seja escrita ou falada, e ocupa-se tanto da coleta como da exploração de corpora.

Ainda segundo o autor, os corpora, por sua vez, podem ser compreendidos como conjuntos de dados linguísticos textuais que são selecionados pelo pesquisador, que previamente define critérios e traça objetivos que irão nortear seus estudos, com o intuito de chegar a uma conclusão sobre algum aspecto específico de uma língua ou variedade linguística analisada no conjunto de corpus (corpora) escolhido.

Mona Baker apresenta-nos os Estudos da Tradução Baseados em Corpus, cujo foco são os textos meta (TMs). A autora define corpus como

[...] um conjunto de textos naturais (em oposição a exemplos/sentenças), organizados em formato eletrônico, passíveis de serem analisados, preferencialmente, em forma automática ou semi-automática (em vez de manualmente). ${ }^{3}$ (BAKER, 1995, p.226; traduzido por Camargo, 2007, p.18)

Baker defende a composição dos Estudos da Tradução Baseados em Corpus aplicada aos textos traduzidos, passando a utilizar-se dos recursos da Linguística de Corpus para avaliar tais textos e entender como o processo tradutório acontece (1996, p. 175). Para a autora (1993), os textos traduzidos registram eventos comunicativos genuínos, que independem de sua natureza e são passíveis de análise em corpus. Sendo assim, uma vez que a tradução fosse devidamente tomada como objeto, teríamos acesso a informações que nos mostrariam o que é e como é levada a cabo: "A questão prática de como melhorar nossas traduções irá encontrar respostas mais confiáveis e realistas uma vez que o fenômeno da tradução será explicado em seus próprios termos”4 (1993, p.243).

\subsection{Os estudos de corpora literários}

Segundo Gonçalves (2007), as pesquisas literárias também têm se beneficiado do que a Linguística de Corpus oferece no que diz respeito a sua eficiência e utilidade para esta área de estudos; a autora afirma que “(é) uma metodologia 
poderosa por conseguir trazer à luz fatos que haviam até agora permanecido escondidos ou passaram despercebidos" (2004, p. 310).

Em Zyngier et. al. (2007b), verifica-se, ainda, o uso de estudos de corpora com o intento de encontrar um "índice de literariedade" para os textos. Tal índice constituir-se-ia de características de uso da linguagem que podem ser descritas com auxílio computacional. Assim, os pesquisadores mapeariam a repetição lexical em diferentes obras da literatura, atribuindo um valor a cada uma das variáveis selecionadas para o índice de literariedade.

Os programas de análise lexical permitiriam, também, apontar três variáveis nos textos de Literatura, dando conta tanto do uso de palavras isoladas como de sequência de palavras (cf. ZYNGIER et. al. 2007c). Uma das variáveis corresponde à frequência relativa de feixes lexicais, indicando em que quantidade as sequências de palavras são encontradas em uma dada obra.

\section{Análise dos resultados}

Primeiramente, com o auxílio da ferramenta WordList, realizamos o levantamento das palavras mais recorrentes no corpus, selecionando aquelas que, de alguma forma, colaboram para a construção da imagem de Aslan em língua inglesa. A seguir, apresentamos a Tabela 1, com as cinco primeiras palavras significativas para esta pesquisa mais frequentes e sua ocorrência no TF.

Tabela 1: Seleção das palavras significativas mais recorrentes no corpus The Lion, the Witch and the Wardrobe

\begin{tabular}{|l|l|l|}
\hline Word & Freq. & $\%$ \\
\hline Lucy & 215 & 0.53 \\
\hline Edmund & 186 & 0.46 \\
\hline Peter & 140 & 0.35 \\
\hline Aslan & 138 & 0.34 \\
\hline Beaver & 132 & 0.33 \\
\hline
\end{tabular}

A primeira palavra de maior frequência na obra em análise é o nome da caçula, Lucy. A menina mostra-nos características que serão reveladoras de Aslan em si, pois, por apresentar exemplar conduta, encontra Nárnia antes de seus irmãos mais velhos, guiados pela razão humana. Sendo assim, implicitamente notamos que há a necessidade da crença, do amor incondicional e da devoção inocente e pura para que Nárnia, no resplendor de sua criação, apresente-se como um mundo novo.

O vocábulo ocorre, no TF, 215 vezes e representa $0.53 \%$ do total do conjunto léxico da obra, permitindo-nos verificar que Lucy é o fio condutor da narrativa. Em The Lion, the Witch and the Wardrobe (1994), a garota configura a infância e a imaginação, bem como a fé constante e o coração puro, que sabemos ser parte integrante dos ensinamentos de Cristo. 
Neste ponto, encontramos um forte paralelo entre o texto da Bíblia Sagrada (1994) e o de Lewis, pois podemos afirmar que Lucy era a mais nova dos irmãos e, portanto, aquela que mais poderia ser considerada, efetivamente, uma criança. Sendo assim, tal circunstância nos remete à ocasião em que Cristo disse aos seus discípulos que não impedissem as crianças de irem até ele, pois a elas pertencia o reino dos céus. Podemos, então, dizer que, da mesma forma como Cristo permitiu a aproximação das crianças por serem donas do reino dos céus, Nárnia permitiu que Lucy a encontrasse, pois além de ser criança, tornar-se-ia rainha daquela terra mágica que lhe pertencia.

Com base nesses aspectos, passamos a analisar alguns trechos em que o nome Lucy aparece dentro do contexto da produção do TF de C. S. Lewis. Para tanto, apresentamos o Quadro 1, com cinco exemplos em contexto:

\footnotetext{
"It seems to me, my dears," said Mrs. Beaver, "that it is very important to know just when he slipped away. How much he can tell her depends on how much he heard. For instance, had we started talking of Aslan before he left? If not, then we may do very well, for she won't know that Aslan has come to Narnia, or that we are meeting him, and will be quite off her guard as far as that is concerned."

"I don't remember his being here when we were talking about Aslan-" began Peter, but Lucy interrupted him.

"Oh yes, he was," she said miserably; "don't you remember, it was he who asked whether the'Witch couldn't turn Aslan into stone too?"
}

And Aslan said nothing either to excuse Peter or to blame him but merely stood looking at him with his great unchanging eyes. And it seemed to all of them that there was nothing to be said.

"Please -Aslan," said Lucy," can anything be done to save Edmund?"

"Welcome, Susan and Lucy, Daughters of Eve. Welcome, He-Beaver and She-Beaver." His voice was deep and rich and somehow took the fidgets out of them. They now felt glad and quiet and it didn't seem awkward to them to stand and say nothing.

At the name of Aslan each one of the children felt something jump in its inside. Edmund felt a sensation of mysterious horror. Peter felt suddenly brave and adventurous. Susan felt as if some delicious smell or some delightful strain of music had just floated by her. And Lucy got the feeling you have when you wake up in the morning and realise that it is the beginning of the holidays or the beginning of summer.

"Is - is he a man?" asked Lucy. "Aslan a man?" said Mr. Beaver sternly. Certainly not. I tell you he is the King of the wood and the son of the great Emperor-beyond-the-Sea. Don't you know who is the King of Beasts? Aslan is a lion - the Lion, the great Lion."

Quadro 1: Trechos com o vocábulo Lucy em The Lion, the Witch and the Wardrobe

Observamos que Lucy cria um vínculo de benevolência para com o seu interlocutor. Notamos, ainda, haver certeza de que ele poderá solucionar problemas de qualquer natureza. A menina vê o Leão como salvador, principalmente ao questionar se haveria alguma coisa a ser feita para que o irmão (Edmund) fosse salvo.

No terceiro trecho, o foco de observação é deslocado e verificamos como Aslan constrói a imagem da garotinha. Pontuamos uma mudança de tom discursivo e uma menção direta à linguagem bíblica quando há a comparação e a 
identificação da raça humana com daughters of Eve. Nesse contexto, podemos até mesmo relacionar o nome de Aslan com o do primeiro homem vivente descrito na Bíblia Sagrada, Adan, o que pode ser uma aproximação fonológica para criar ambiguidade ${ }^{5}$, visto que Aslan representaria Jesus, que, na visão do Cristianismo, veio ao mundo em forma de homem.

No quarto exemplo, podemos afirmar que Lucy e Edmund, a partir do papel que assumem dentro da narrativa, servem como reflexos de Aslan e colaboram para a construção de suas bases interpretativas.

Ao ouvir o nome do Leão, os quatro irmãos têm sensações diferentes, entre as quais a de Lucy parece ser a mais autêntica e condizente com o que eles estavam para viver em Nárnia, enquanto Edmund tem uma sensação horrível, proveniente de seu envolvimento com o mal. É interessante observar que a descrição começa com o menino e termina com sua irmã caçula, colocando-os, assim, em destaque com relação a Suzan e Peter, que parecem equilibrar as sensações com neutralidade.

Por fim, verificamos que é por meio de Lucy que se esclarece o mistério de Aslan; ou seja, com as indagações da criança é que se inicia o desvendar da identidade do lion.

Novamente, ousamos dizer que Lucy se coloca como reflexo de Aslan, nos mostrando o que ele é e o que ele não é; como uma iniciada nos valores de Nárnia, ela indaga, no entanto, sem nunca duvidar, o que a transforma em um elo com o sobrenatural.

Com base nestes dados, verificamos, também, a tabela de patterns do TO, a qual apresentamos na Figura 1, a seguir:

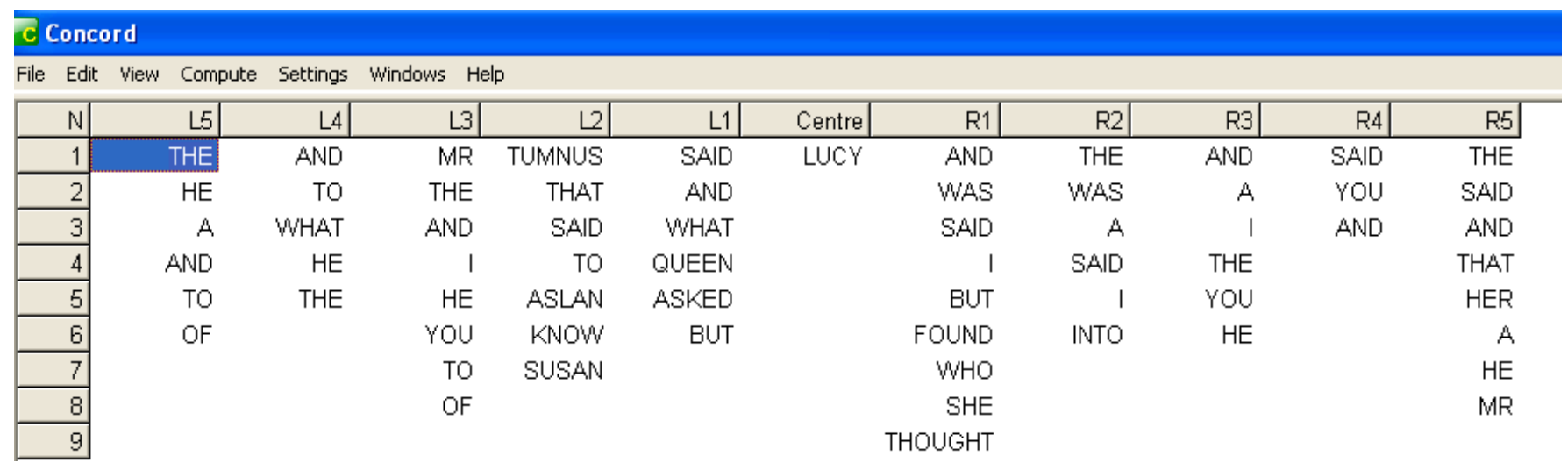

Figura 1: Patterns para Lucy em The lion, the witch and the wardrobe

Por meio dessas informações, podemos observar que os nomes Lucy e Aslan apresentam uma proximidade grande dentro da obra, de forma que, na maior parte das vezes, o nome do Leão ocorre a cada duas palavras de distância à esquerda da palavra $L u c y$. Isso nos permite constatar a inter-relação que o autor constitui entre os personagens, promovendo um vínculo metafórico e ideológico entre a criança e o salvador. 
A segunda palavra de maior frequência é Edmund. Nome de um dos personagens protagonistas, irmão do meio de Lucy. O menino, como mencionamos anteriormente, assume caráter relevante, pois, ao ficar ao lado da White Witch, causa o conflito, o nó da história, que terá, então, de ser resolvido para que o pior não aconteça.

Assim como Aslan e a White Witch, Edmund representa o polo oposto de Lucy: maldoso, ofensivo, rancoroso e mentiroso. Na narrativa, temos a impressão de que o caráter das personagens as guia pela terra de Nárnia; ou seja, enquanto Lucy encontra Mr. Tumnus, representante do bem, Edmund encontra a própria feiticeira, principal referência do mal.

A forma como Edmund é tratado pela bruxa entra em contraste com a bondade, o amor e o senso de justiça de Aslan, pois ele decide se sacrificar no lugar do traidor.

Edmund é a prova de que nem uma grande ofensa como a traição é capaz de alterar o caráter de Aslan. Vejamos quais as relações que se estabelecem entre os personagens dentro do contexto da obra por meio do Quadro 2:

\footnotetext{
"If you please, sir," said Edmund, trembling so that he could hardly speak, "my name is Edmund, and I'm the Son of Adam that Her Majesty met in the wood the other day, and I've come to bring her the news that my brother and sisters are now in Narnia -quite close, in the Beavers' house. She -she wanted to see them."
}

"How dare you come alone?" said the Witch in a terrible voice. "Did I not tell you to bring the others with you?"

"Please, your Majesty," said Edmund, "I've done the best I can. I've brought them quite close. They're in the little house on top of the dam just up the river -with Mr. and Mrs. Beaver."

"Is this all your news?" she asked.

"No, your Majesty," said Edmund, and proceeded to " tell her all he had heard before leaving the Beavers house."What! Aslan?" cried the Queen. "Aslan! Is this true? If I find you have lied to me-"

"Please, I'm only repeating what they said stammered Edmund.

As soon as they had breakfasted they all went out, and there they saw Aslan and Edmund walking together in the doty grass, apart from the rest of the court. There is no need to tell you (and no one ever heard what Aslan was saying, but it was a conversation which Edmund never forgot. As the others drew nearer, Aslan turned to meet them, bringing Edmund with him.

'When once Aslan had been tied (and tied so that he was really a mass of cords) on the flat stone, a hush fell on the crowd. Four Hags, holding four torches, stood at the corners of the Table. The Witch bared her arms as she had bared them the previous night when it had been Edmund instead of Aslan.

Quadro 2: Ocorrências do vocábulo Edmund em The Lion, the Witch and the Wardrobe

Nos três primeiros exemplos extraídos da obra de C. S. Lewis, notamos que a construção da personagem de Edmund, bem como as alegorias da obra que estabelecem o vínculo com o discurso do bem e do mal, também estão presentes no Cristianismo.

No entanto, essa relação se firma claramente nas escolhas léxico-semânticas do autor, visto que o jovem rapaz trai não somente uma crença, como também 
traz à baila a grave traição bíblica de Judas, discípulo de Jesus, que o entregou aos sacerdotes e líderes religiosos que o queriam matar.

No quarto contexto retirado do TF, notamos o primeiro momento em que Aslan e Edmund encontram-se, quando as personagens são vistas conversando enquanto caminham lado a lado. Nesse momento, percebemos a ausência do horror que Edmund havia sentido quando, também pela primeira vez, ouvira o nome de Aslan, o que indica o arrependimento e a mudança do personagem, que a partir desse momento deixa de configurar o reflexo do que Aslan não é para revelar o que ele é: perdão, graça, misericórdia e amor. Torna-se relevante destacar, também, que quando verificamos a construção semântica que associa Edmund com a White Witch, é possível notar uma atmosfera de medo, angústia e maldade.

Compreende-se o amedrontamento, no primeiro excerto, pela sentença: said Edmund, trembling so that he could hardly speak. A desaprovação de sua ação o leva a temer as consequências. Além disso, a bruxa vive em um mundo de congelamento, frieza e perversidade.

O tom malevolente da White Witch transfigura-se em ameaças claras, como em: How dare you come alone?ou If I find you have lied to me. Desse modo, as escolhas de composição lexical e a ordem com que o escritor faz uso delas colocamnos diante de um conjunto de características que envolvem Edmund, a princípio, em um ambiente de carga negativa e o associam ao mau comportamento, ou seja, aquele que não condiz com as premissas de Nárnia.

No quarto excerto, observamos a volta do menino, como um "filho pródigo" que pede perdão e é absolvido pela compaixão do "Pai", assim como no quinto excerto, em que o narrador faz questão de frisar que Aslan estava morrendo no lugar de Edmund, para cumprir a exigência da White Witch, que reclamou o direito sobre o sangue do humano, devido a sua traição. Aslan, conhecedor das leis, entrega-se no lugar de Edmund, sabendo que a morte seria desfeita se um inocente voluntário morresse no lugar de um traidor.

Assim como realizamos com o vocábulo Lucy, abaixo apresentamos a Figura 2 com os patterns para a palavra Edmund no TF:

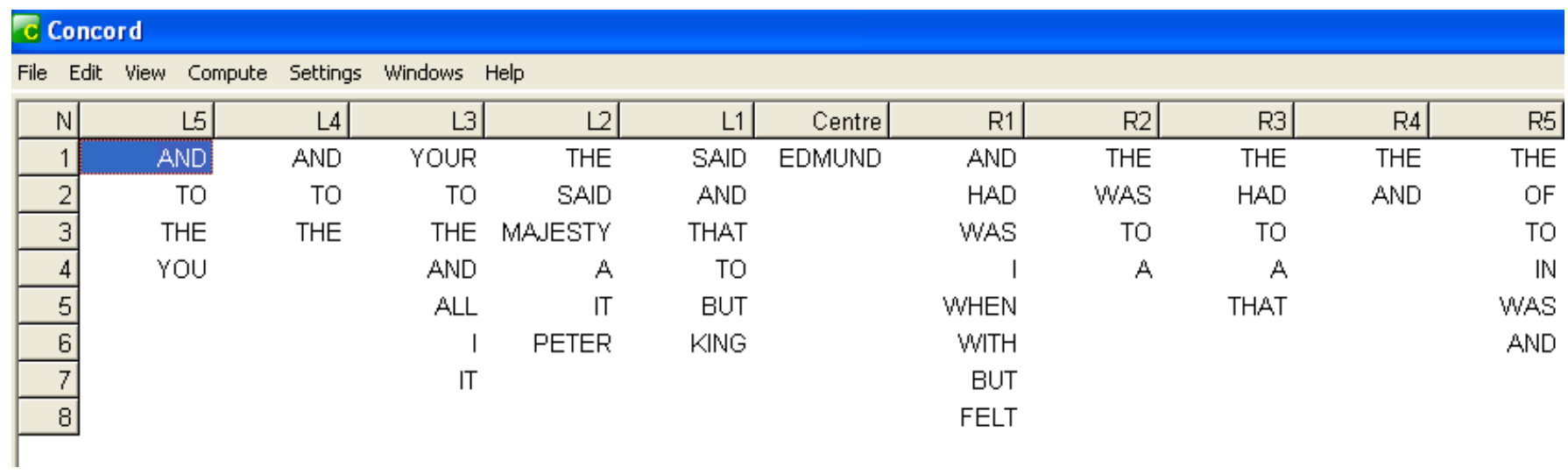

Figura 2: Patterns para Edmund em The Lion, the Witch and the Wardrobe 
Por meio dessas informações é possível perceber que o vínculo com Majesty, título atribuído à bruxa, é mais reincidente. Vemos, também, o vínculo com $P e$ ter, irmão mais velho que o repreende diversas vezes e assume a função de tentar neutralizar a tendência à rebeldia.

A terceira palavra que selecionamos para análise é Aslan, objeto principal de nossa pesquisa e sobre o qual nos deteremos com maior interesse, também chamado de The Great Lion e son of the great Emperor-beyond-the-Sea. O nome Aslan ocorre 147 vezes na narrativa e compõe $0,39 \%$ da obra, o que comprova sua importância como protagonista, pois é o criador e grande Rei de Nárnia.

Por meio dele, principalmente, é que podemos estabelecer a principal relação intertextual com a Bíblia Sagrada, especificamente nos evangelhos do Novo Testamento, nos quais encontramos toda a história de Jesus Cristo: sua vida, morte e ressurreição.

Aqui, torna-se relevante notar que, assim como os evangelhos são compostos por quatro livros (Mateus, Marcos, Lucas e João), a profecia em Nárnia diz respeito a quatro humanos (Peter, Suzan, Edmund e Lucy), que preencherão os tronos de Cair Paravel. Podemos supor, considerando menções bíblicas, como "os quatro cantos da terra" e "os quatro ventos", que o número quatro represente a terra, neste caso, seus representantes em Nárnia.

Como nos exemplos anteriores, apresentamos o Quadro 3, com as ocorrências em contexto do vocábulo Aslan no TF:

"Then in the name of Aslan," said Queen Susan "if ye will all have it so, let us go on and take the adventure that shall fall to us."

"Daughter of Eve," said Aslan in a graver voice, "others also are at the point of death. Must more people die for Edmund?"

During the first part of the journey Aslan explained to Peter his plan of campaign. "As soon as she has finished her business in these parts," he said," the Witch and her crew will almost certainly fall back to her House and prepare for a siege.

Great Hall of Cair Paravel -that wonderful hall with the ivory roof and the west wall hung with peacocks' feathers and the eastern door which looks towards the sea, in the presence of all their friends and to the sound of trumpets, Aslan solemnly crowned them and led them to the four thrones amid deafening shouts of, "Long Live King Peter! Long Live Queen Susan! Long Live King Edmund! Long Live Queen Lucy!"

Wrong will be right, when Aslan comes in sight, At the sound of his roar, sorrows wilt be no more, When he bares his teeth, winter meets its death, And when he shakes his mane, we shall have spring again. You'll understand when you see him."

Quadro 3: Ocorrências do vocábulo Aslan em The Lion, the Witch and the Wardrobe

Na primeira ocorrência, verificamos uma invocação do nome de Aslan, feita por Suzan. Considere-se que, neste momento, os quatro irmãos já estão vivendo há muito tempo em Nárnia e já não veem Aslan desde a noite de sua coroação, depois de terem vencido a White Witch. Entretanto, a lembrança e a honra ao seu nome permanecem no coração dos reis e rainhas de Nárnia. Da mesma forma, no 
Cristianismo, o nome de Jesus atravessou os séculos e continua sendo invocado em diversas situações pelos cristãos, que reconhecem, exaltam e honram este nome.

No segundo excerto, Aslan dá uma ordem a Lucy com o tom de conselho, o que deixa claro que ele não exerce sobre os seus a mesma autoridade que a White Witch. Gentilmente, Aslan leva-a a refletir sobre o motivo de obedecer-lhe naquele momento, ressaltando sua benignidade em dar-lhe a escolha de ouvi-lo ou não.

No terceiro exemplo, quando Aslan está passando para Peter o plano de batalha, temos a sensação de que guerrear lhe é bastante comum, o que nos remete à narrativa bíblica quando encontramos, muitas vezes, o termo "Senhor dos Exércitos" para se referir a Deus. A Bíblia Sagrada relata inúmeras histórias, no Velho Testamento, que foram vencidas graças aos planos e orientações de combate dadas por Deus ao seu povo e, em ambos os testamentos, fala-se de um Deus com estratégias infalíveis, invicto nas pelejas:

Então disse o SENHOR a Josué: Olha, tenho dado na tua mão a Jericó, ao seu rei e aos seus homens valorosos. Vós, pois, todos os homens de guerra, rodeareis a cidade, cercando-a uma vez; assim fareis por seis dias. E sete sacerdotes levarão sete buzinas de chifres de carneiros adiante da arca, e no sétimo dia rodeareis a cidade sete vezes, e os sacerdotes tocarão as buzinas. E será que, tocando-se prolongadamente a buzina de carneiro, ouvindo vós o seu sonido, todo o povo gritará com grande brado; e o muro da cidade cairá abaixo, e o povo subirá por ele, cada um em frente. [...] Gritou, pois, o povo, tocando os sacerdotes as buzinas; e sucedeu que, ouvindo o povo o sonido da buzina, gritou o povo com grande brado; e o muro caiu abaixo, e o povo subiu à cidade, cada um em frente de si, e tomaram a cidade. (Livro de Josué, capítulo 6, versos 2, 3, 4, 5 e 20, grifo nosso.)

E Davi tornava-se cada vez mais forte; porque o Senhor dos Exércitos era com ele. (BÍBLIA, Livro de I Crônicas, 11, 9 [grifo nosso])

O quarto excerto é parte dos momentos finais da primeira crônica de Nárnia, em que todos estão reunidos em Cair Paravel para uma grande festa, depois de terem vencido a batalha. Assim como há uma promessa feita por Deus na narrativa bíblica (BÍBLIA, Livro de Apocalipse, 3, 21) de que, a todo aquele que vencer, Ele lhe concederá que se assente no trono, Aslan leva os reis e rainhas de Nárnia, que venceram a batalha, para seus tronos.

Além disso, há diversas referências bíblicas a respeito da simbologia da coroa, que significa poder e autoridade. É reforçada a visão de Aslan como criador de Nárnia e detentor de poder, de autoridade e de todo tipo de honrarias que ele dará aos que estiverem ao seu lado.

Também verificamos a relação dos patterns de Aslan em contexto, os quais estão ilustrados na figura 9: 


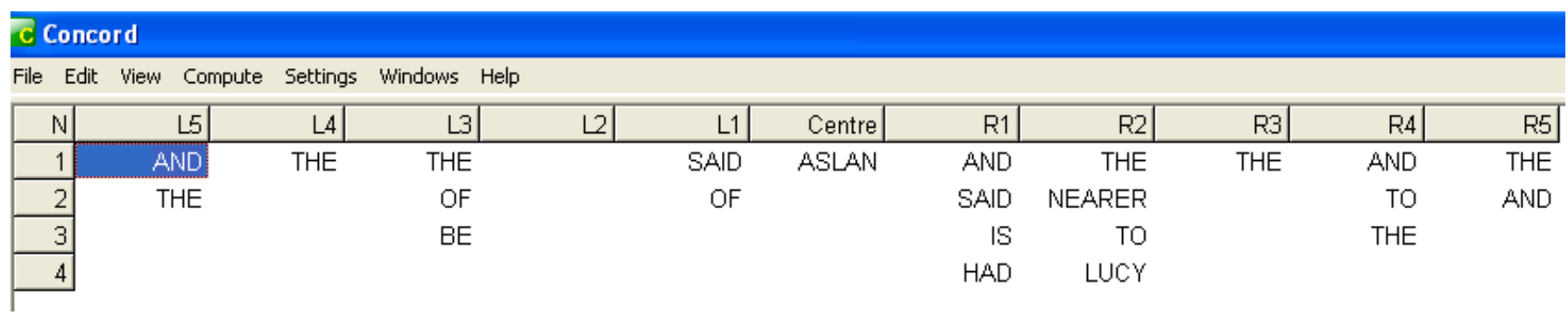

Figura 3: Patterns para Aslan em The Lion, the Witch and the Wardrobe

Na relação com o vocábulo Aslan, observamos a repetição da palavra said em torno de Aslan, evidenciando, assim, o registro dos discursos diretos, ou seja, dando ênfase ao que ele dizia em toda a narrativa, assim como é feito com Jesus em suas parábolas. Portanto, podemos dizer que Aslan detém o poder da palavra dentro da narrativa.

Por fim, embora não conste em nossa lista de palavras mais frequentes selecionadas, consideramos importante observar a relação que se estabelece com as referências ao animal leão, como representação de força, majestade, bem como de poder e temor. O vocábulo Lion ocorre 43 vezes e pudemos verificar que quando se refere a Aslan, ele aparece com a letra inicial maiúscula, característica de nomes próprios, ou seja, demonstra a identidade e o destaca em relação ao outro leão que aparece na narrativa.

Dessa forma, salientamos que o termo Lion no TF permite-nos questionar de que forma este vocábulo auxilia na construção de sua imagem e se, em português, há a mesma carga de sentido. Se somarmos esse número ao número de vezes em que o nome Aslan é mencionado, vemos um aumento na menção à personagem, de modo que ele é citado, ou referenciado em 178 trechos.

Abaixo, apresentamos, por conseguinte, o quadro quatro, com cinco ocorrências do vocábulo em contexto:

"Aslan a man!" said Mr Beaver sternly. "Certainly not. I tell you he is the King of the wood and the son of the great Emperor-beyond-the-Sea. Don't you know who is the King of Beasts? Aslan is a lion--the Lion, the great Lion."

"Probably," he thought, "this is the great Lion Aslan that they were all talking about. She's caught him already and turned him into stone. So that's the end of all their fine ideas about him! Pooh! Who's afraid of Aslan?"

Then at last Peter realised that it was up to him. He drew his sword and raised it to the salute and hastily saying to the others "Come on. Pull yourselves together," he advanced to the Lion and said: "We have come--Aslan."

The Lion shook his mane and clapped his paws together ("Terrible paws," thought Lucy, "if he didn't know how to velvet them!") and said, "Meanwhile, let the feast be prepared. Ladies, take these Daughters of Eve to the pavilion and minister to them."

Quadro 4: Ocorrências do vocábulo Lion em The lion, the Witch and the Wardrobe

O primeiro excerto consiste no primeiro momento em que o vocábulo Lion é mencionado dentro da narrativa, curiosamente, por meio do personagem $\mathrm{Mr}$. 
Beaver, que explica que Aslan é um Leão e não um humano. O próprio personagem já especifica, após essa informação, que Aslan é especial, o grande leão, deixando claro que não há outro que se equipare ou compare a ele. Devemos lembrar, aqui, que Lion está no título da obra de Lewis e também acompanhado pelo artigo definido the, assim como nesta passagem, que pressupõe a ideia de superioridade deste ser e de mistério sobre sua identidade.

No segundo trecho, percebemos que, mesmo na fala de Edmund, o autor mantém o vocábulo Lion com letra inicial maiúscula, o que pode demonstrar que, apesar de estar desdenhando, por lhe ser conveniente no momento, ou Edmund reconhece a posição de Aslan em Nárnia ou o autor desejou manter a letra maiúscula para ressaltar o caráter imutável e inatingível ${ }^{6}$ da personagem.

O terceiro exemplo mostra-nos o narrador referindo-se a Aslan como the Lion, o que reafirma a ideia de que o autor tenha construído a imagem de Aslan sobre o conceito e as alegorias acerca do animal leão, adicionando a este a característica de único em sua qualidade, superior aos outros.

No quarto excerto, o narrador nos conta que Aslan sacudiu sua juba e, para nossa surpresa e estranhamento, bateu suas patas, como quem chama a atenção dos servos para lhes dar uma orientação. Aqui fica claro que, apesar de ser um animal, Aslan age com inteligência emocional e gestos esperados de um ser humano e que esse detalhe também é parte integrante dos elementos agregados a sua imagem.

Considerando a base que construímos com a análise dos vocábulos pertinentes ao objetivo do presente trabalho, prosseguimos com as considerações sobre as opções do tradutor, Paulo Mendes Campos, procurando expor possíveis diferenças de caráter semântico ocorridas no processo de transposição da narrativa para a língua portuguesa.

\subsection{As opções de tradução e a intertextualidade}

A fim de analisarmos as opções de tradução, utilizamos a ferramenta Concord do programa WordSmith Tools, que nos permitiu selecionar cinco ocorrências do nome Aslan, cinco de Edmund e cinco de Lucy, para compará-las, então, as suas respectivas traduções, igualmente coletadas com o mesmo utilitário.

Apresentamos, a seguir, nossas considerações sobre os excertos, original e tradução retirados das obras em questão:

\subsection{1 "Lúcia"}

"Please--Aslan," said Lucy, “can anything be done to save Edmund?”

- Por favor... Aslam - disse Lúcia -, não podemos fazer algo para salvar Edmundo?

No trecho acima, o tradutor decidiu modificar levemente o tom da pergunta e acrescentou o sujeito oculto "nós". Ao traduzir can anything be done to save Edmund? por “não podemos fazer algo para salvar Edmundo?",e não “alguma coisa 
pode ser feita para salvar Edmundo?",o tradutor aproximou, nesta fala, a menina "Lúcia" e seu interlocutor, "Aslam", enfatizando o vínculo já explorado. Além disso, no TM vemos a ação sendo praticada pela própria personagem, uma vez que a voz ativa leva-nos a compreender que quem ajudará "Edmundo" é sua irmã e o leão. Parece-nos, então, que a menina assume o caráter de auxiliadora, toma para si a atitude de reverter a maldade e de amparar o "filho pródigo", o qual, agora, pede por auxílio do criador.

"Oh, you're real, you're real! Oh, Aslan!" cried Lucy, and both girls flung themselves upon him and covered him with kisses.

- Não! Você está vivo! Oh, Aslam! - gritou Lúcia, e as duas meninas atiraram-se sobre ele com mil beijos.

Neste ponto, a escolha tradutória por "Você está vivo!" para you're real, you're real!, contribui significativamente para a construção da alegoria entre o personagem Aslam e Cristo, pois reforça a ideia da ressurreição, que remete, inevitavelmente, ao ponto mais marcante da narrativa bíblica.

Lucy was running towards him as fast as her short legs would carry her and her face was as white as paper.

Pálida como a neve, Lúcia corria para ele com suas perninhas curtas.

Neste momento de tensão na narrativa, o tradutor optou por mudar a metáfora usada para expressar o medo e o terror de "Lúcia". Ao invés de traduzir as white as paper como "branca como papel", ele usou "pálida como a neve", trazendo à tona um importante item da representação do mal em Nárnia: a neve.

And then he was silent again for some time. Up to that moment Lucy had been thinking how royal and strong and peaceful his face looked; now it suddenly came into her head that he looked sad as well. But next minute that expression was quite gone. The Lion shook his mane and clapped his paws together ("Terrible paws," thought Lucy, "if he didn't know how to velvet them!")

O Leão guardou silêncio por certo tempo. Lúcia então reparou que sua expressão (apesar de imponente, régia e calma) também era triste. Mas a tristeza não demorou muito. Ele sacudiu a juba, bateu as patas ("Que terríveis patas seriam" -pensou Lúcia - "se ele não soubesse como torná-las macias!")

Neste excerto, vemos, mais uma vez, o desvendar do personagem "Aslam" pelos olhos de "Lúcia", a mais sensível entre os irmãos Penvensie. O tradutor simplificou a frase Up to that moment Lucy had been thinking how royal and strong and peaceful his face looked; now it suddenly came into her head that he looked sad as well; e usou a conjunção adversativa "apesar de" para ressaltar o contraste entre “imponente, régia, calma e triste". Em seguida, optou pela palavra "terrível", que assim como terrible, no inglês, também carrega a ideia de algo grande, extraordi- 
nário, fora do comum, que está, novamente, em contraste com "torná-las macias", sua opção de tradução para to velvet them, ao invés de "aveludá-las".

Portanto, as mudanças que o tradutor realiza não culminam em perda de sentidos e metáforas; pelo contrário, ele mantém a relação de contraste estabelecida, criando novas possibilidades interpretativas e associando elementos distintos do conjunto léxico utilizado pelo autor para construir significações e fantasias que se aproximam do TF.

\subsection{2 "Edmundo"}

Edmund was a graver and quieter man than Peter, and great in council and judgement. He was called King Edmund the Just.

Edmundo era mais grave e calado do que Pedro, muito sábio nos conselhos de Estado. E foi chamado de Edmundo, o Justo.

Neste exemplo, temos a descrição da fase adulta da personagem "Edmundo" em Nárnia, na qual o tradutor manteve a comparação feita sem traduzir a palavra man, e, em seguida, optou por apresentar great como "muito sábio". A ideia de sabedoria, aqui, parece retomar a fase adulta que foi suprimida pela não tradução do termo man. Devemos lembrar que esse momento acontece depois de "Edmundo" ter um encontro com "Aslam" e ser redimido da traição; ou seja, a não tradução da palavra man no TM pode sugerir que essa mudança tenha acontecido logo depois de ter encontrado o "Leão" e mudado de atitude, ainda criança, e que a sabedoria nos conselhos, esta, sim, tenha vindo com o passar dos anos. Tal hipótese evidencia o poder transformador de "Aslam" no TM, fortalecendo a intertextualidade cristã.

The two elder ones did this without meaning to do it, but Edmund could be spiteful, and on this occasion he was spiteful. He sneered and jeered at Lucy and kept on asking her if she'd found any other new countries in other cupboards all over the house.

Os dois mais velhos faziam isso sem querer, mas Edmundo costumava bancar o mau, e estava sendo mau daquela vez. Zombava de Lúcia, chateando-a o tempo todo, perguntando se ela não tinha achado outras terras misteriosas nos numerosos armários que existiam por toda a casa.

Aqui o narrador especifica que "Edmundo" era diferente dos outros; ou seja, na expressão could be spitful, há a conotação da capacidade que o menino tinha de agir de certa forma. Na tradução, contudo, optou-se por "costumava bancar o mau", que, diferente do original, sugere que ele não só tinha essa capacidade, como agia assim frequentemente, o que entra em concordância com a afirmação da oração subsequente, justificando a escolha do tradutor. Em seguida, o tradutor encontrou em "zombar" e "chatear" os melhores correspondentes para sneer e jeer, já que este último representa uma expressão facial, um sorriso de desdém.

Nesta e em outras cenas, "Lúcia" e "Edmundo" são colocados em evidência, pois, tanto um como o outro, são crianças cujas atitudes são cruciais para o de- 
senrolar dos acontecimentos, e, na tradução, a mesma ideia vai sendo elaborada, embora de uma forma diferente, que causará, contudo efeitos semelhantes no leitor da Língua de Chegada (LC).

"I’ve come, your Majesty," said Edmund, rushing eagerly forward.

"How dare you come alone?" said the Witch in a terrible voice. "Did I not tell you to bring the others with you?"

- Aqui estou, Majestade - disse Edmundo, avançando, aflito.

- Como se atreve a vir sozinho? - perguntou a feiticeira em tom de ameaça. - Não dei ordem para que trouxesse seus irmãos?

Nesta passagem, "Edmundo" encontra a "Rainha Branca" pela segunda vez e ainda está pensando que ela é a pessoa bondosa que demonstrou ser a princípio. Ele está ludibriado pelas promessas de se tornar rei e poder comer mais da guloseima que a bruxa lhe ofereceu, por isso nos deparamos, no original, com rushing eagerly forward. Nessa descrição, o tradutor optou por "avançando, aflito", como um pressentimento de que irá ser maltratado. Portanto, o tradutor adianta para o leitor do TM a condição de "Edmundo" ao lado da bruxa.

As the others drew nearer Aslan turned to meet them, bringing Edmund with him."Here is your brother,"he said, "and--there is no need to talk to him about what is past."

Quando os outros se aproximaram, Aslam voltou-se e, acompanhado por Edmundo, foi ao encontro deles.

- Aqui está o quarto Filho de Adão. E... bem... não vale a pena falar do que aconteceu. O que passou, passou.

No trecho acima, "Aslam" apresenta "Edmundo" para os irmãos, depois de seu resgate. No original, temos Here is your brother, enquanto o tradutor optou por "Aqui está o quarto Filho de Adão", termo que faz lembrar a natureza falha e corruptível do ser humano, visto que Adão foi o homem que, na narrativa bíblica, junto a sua mulher, Eva, foi enganado pela serpente. "Edmundo" havia sido enganado pela bruxa, mas agora estava com "Aslam", não importando, assim, seus atos anteriores: "não vale a pena falar do que aconteceu" (LEWIS, p. 167).

\subsection{3 "Aslam"}

"Turn him into stone? If she can stand on her two feet and look him in the face it'll be the most she can do and more than I expect of her. No, no. He'll put all to rights as it says in an old rhyme in these parts: Wrong will be right, when Aslan comes in sight, At the sound of his roar, sorrows will be no more, When he bares his teeth, winter meets its death, And when he shakes his mane, we shall have spring again. [...]"

- Transformar ASLAM em pedra? Se ela conseguir manter-se em pé diante dele, olhálo cara a cara, já é caso para dar-lhe os parabéns.Não, não. Ele vem botar tudo nos eixos. Assim diz um velho poema que costumamos cantar: 


\section{O mal será bem quando Aslam chegar, \\ Ao seu rugido, a dor fugirá, \\ Nos seus dentes, o inverno morrerá, \\ Na sua juba, a flor há de voltar.}

O excerto exposto acima compõe uma das falas da personagem "Sr. Castor", enquanto este explica para as crianças tudo a respeito de Nárnia, do "Leão" e do papel delas mesmas na terra mágica. Ao invés de traduzir Turn him into stone? por “Transformá-lo em pedra?", como seria o esperado, o tradutor optou por usar o nome de "Aslam", em caixa alta, dando ênfase à personagem. Por conseguinte, verificamos que o tradutor usou "O mal será bem", ao invés de "O errado será certo", para Wrong Will be right. Supomos que essa escolha tenha sido baseada no fato de se querer manter a linearidade de ideias. Além disso, a rima também se apresenta de forma diferente do TO, separada do corpo do texto, tomado um formato de verso.

"What is your message, Son of Earth?" asked Aslan.

- A que vens, Filho da Terra? - perguntou Aslam.

Neste trecho, percebemos que o tradutor usa a erudição típica da linguagem bíblica, remetendo, assim, diretamente às Escrituras Sagradas, principalmente a um momento, descrito no Livro de Jó, em que, assim como o anão inimigo entrou na presença de "Aslam", Satanás, o inimigo de Deus, entra em sua presença: "Então o SENHOR disse a Satanás: Donde vens? E Satanás respondeu ao SENHOR, e disse: De rodear a terra, e passear por ela (BÍBLIA, Livro de Jó, 1, 7 [grifo nosso]). Portanto, a instrução usada pelo tradutor colabora, fortalecendo os laços entre o texto de Lewis e a Bíblia Sagrada no TT.

“That, O Man," said Aslan, "is Cair Paravel of the four thrones, in one of which you must sit as King.

- Aquilo, ó humano, é Cair Paravel, dos quatro tronos, num dos quais você há de sentar-se como rei.

No excerto anterior, observamos, mais uma vez, a retomada da linguagem bíblica, que ocorre devido à interjeição $O$ Man, traduzida por "ó humano", como neste exemplo: "Mas, ó homem, quem és tu, que a Deus replicas?” (BÍBLIA, Carta aos Romanos, 9, 20 [grifo nosso]).

"Then in the name of Aslan," said Queen Susan, "if ye will all have it so, let us go on and take the adventure that shall fall to us."

- Então, em nome de Aslam - disse Susana -, se o desejo de todos vós é esse, continuemos em busca da aventura que nos aguarda.

Neste último excerto, notamos mais um exemplo de referência indireta à linguagem sagrada, pois se remete à expressão "em nome de Jesus", a qual encon- 
tramos na Bíblia Sagrada e na linguagem dos cristãos, que usam frequentemente a referida expressão. Este verso é um dos exemplos: "Dando sempre graças por tudo a nosso Deus e Pai, em nome de nosso Senhor Jesus Cristo" (BÍBLIA, Livro de Efésios, 5, 20 [grifo nosso]).

Considerando o percurso que traçamos, podemos afirmar que a tradução realizada por Paulo Mendes Campos manteve, em muitos aspectos, as analogias construídas por C. S. Lewis em sua história. Portanto, nesta subseção, ampliamos a análise das principais intertextualidades criadas em torno da personagem "Aslam" e citamos trechos da Bíblia Sagrada que comprovam tal relação entre os dois textos. Selecionamos a Holy Bible, King James' version (2000), versão adotada pela Igreja Anglicana, a qual Lewis passou a frequentar depois de seu retorno ao cristianismo.

A Bíblia apresenta várias metáforas para se referir a Deus e, nas particularidades de cada uma, revela pontos de Sua identidade, visto que Ele não pode ser refletido ou encontrado em apenas uma simbologia ou referencial terreno. Algumas alegorias bíblicas que encontramos a respeito de Deus são, o fogo; "Porque o nosso Deus é um fogo consumidor" (BÍBLIA, Epístola aos Hebreus, 12, 29), a água; "Porque o meu povo fez duas maldades: a mim me deixaram, o manancial de águas vivas, e cavaram cisternas, cisternas rotas, que não retêm águas" (Livro de Jeremias, capítulo 2, verso 13), o Cordeiro; "No dia seguinte João viu a Jesus, que vinha para ele, e disse: Eis o Cordeiro de Deus, que tira o pecado do mundo" (Evangelho de João, capítulo 1, verso 29), e, também, o Leão; "E disse-me um dos anciãos: Não chores; eis aqui o Leão da tribo de Judá, a raiz de Davi, que venceu, para abrir o livro e desatar os seus sete selos" (Livro de Apocalipse, capítulo 5, verso 5).

Portanto, Deus se revela na propriedade de fogo, pois, assim como este serve para purificar metais nobres como o ouro e a prata; Deus consome todo o pecado, a impureza; ou seja, Sua natureza é totalmente oposta a estes. Por meio desta metáfora, a Bíblia Sagrada deixa claro que Deus é santo.

Ao se definir como água viva, Deus, na narrativa bíblica, nos revela outra característica de Si mesmo: Provedor de vida. Sabemos ser a água um elemento essencial para a existência de vida, e Deus promete, então, prover essa vida os Seus filhos, bem como suprir todas as necessidades, figurativamente, sua "sede".

Na figura de Cordeiro é revelado o amor incondicional de Cristo, que se entrega voluntariamente e sem oferecer resistência ao ser levado para a morte. Além desse aspecto, torna-se válido lembrarmo-nos que este animal era usado nos sacrifícios do Antigo Testamento bíblico para a expiação dos pecados do povo, diariamente. Uma vez que Deus enviou Seu filho para morrer pela humanidade, o sacrifício diário dos animais fez-se desnecessário, pois Jesus Cristo foi o "cordeiro" perfeito, único homem sem pecado, cujo sacrifício é válido para sempre. Portanto, a metáfora do Cordeiro leva os cristãos a reconhecerem que Deus é amor, pois se entrega à morte para salvar o mundo.

Finalmente, o termo Leão da Tribo de Judá, refere-se a Cristo que, como previu a profecia, nasceu em uma família que pertencia a esta tribo (uma das doze tribos dos filhos de Jacó). O Leão, neste ponto, se refere ao mais nobre, o mais forte, 
o mais honrado, o mais poderoso e o mais importante homem desta tribo: Jesus Cristo. Percebe-se, portanto, que no termo Leão é aquele em que podemos reconhecer mais características de Deus, o que torna tal metáfora muito forte no campo semântico, justificando a escolha de C. S. Lewis para a representação de "Aslam".

No título, o vocábulo Leão ainda fica confuso entre os outros dois (a feiticeira e o guarda-roupa), pois não conseguimos imaginar que tipo de relação estes três elementos podem ter dentro da história. Entretanto, à medida que somos apresentados à narrativa, a alegoria do Leão ganha força e, de forma gradativa, também fortalece a intertextualidade ali presente, possibilitando, assim, o reconhecimento de Cristo na figura de Aslan (Aslam), como nos exemplos a seguir, extraídos da tradução, O leão, a feiticeira e o guarda-roupa (2002) e da Bíblia Sagrada:

- Mas e o coitado do Sr. Tummus? - perguntou Lúcia.

- O melhor meio para salvá-lo é procurar Aslam - disse o castor. -Enquanto ele não chegar, não podemos agir. (p. 98)

- Mas não há ninguém que possa ajudar a gente?

- Só Aslam - sentenciou o Sr. Castor. - Vamos procurá-lo. É a nossa única esperança. (p. 106)

Nos trechos citados, notamos que "Aslam" é colocado em evidência em momentos de desespero e indagação, assim como Cristo, no trecho bíblico visto anteriormente (BÍBLIA, Livro de Apocalipse, 5, 5). Portanto, no momento em que encontramos o ápice da intertextualidade na narrativa de Lewis, o autor já se valeu de uma técnica de gradação para nos preparar para tal momento, de forma que, mesmo o leitor que não tem muito contato com a narrativa bíblica é capaz de reconhecer a relação ali estabelecida:

Claro que, se o Leão quisesse, uma patada seria a morte para eles. Mas ficou quieto, mesmo quando os inimigos rasgaram a sua carne de tanto esticarem as cordas. Depois, começaram a arrastá-lo para o centro da mesa. (p. 184)

Ele foi oprimido e afligido, mas não abriu a sua boca; como um cordeiro foi levado ao matadouro, e como a ovelha muda perante os seus tosquiadores, assim ele não abriu a sua boca (BÍBLIA, Livro de Isaías, 53, 7).

"Aslam" é sacrificado, sem oferecer resistência. A força do Leão sucumbe para dar lugar à mansidão do Cordeiro, que caminha para a morte voluntariamente: "Eis o Cordeiro de Deus, que tira o pecado do mundo" (BÍBLIA, Evangelho de João, 1,29). Depois do sacrifício, vemos uma série de acontecimentos com os quais iremos intercalar os respectivos versos bíblicos da alegoria estabelecida:

Foi quando ouviram um grande barulho, um barulho ensurdecedor de uma coisa que estala, como se um gigante acabasse de quebrar um prato gigantesco $[\ldots]$. Até que viram. A Mesa de Pedra estava partida em duas por uma grande fenda, que ia de lado a lado. E de Aslam, nem sombra. (p. 193 e 194) 
E eis que houvera um grande terremoto, porque um anjo do Senhor, descendo do céu, chegou, removendo a pedra da porta, e sentou-se sobre ela. [...] Ele não está aqui, porque já ressuscitou como havia dito. Vinde, vede o lugar onde o Senhor jazia (BÍBLIA, Evangelho de Mateus, 28, 2 - 12).

- Aslam! Aslam! - exclamaram as meninas, espantadas, olhando para ele, ao mesmo tempo assustadas e felizes.

- Pareço um fantasma?

- Não! Você está vivo! Oh, Aslam! - grito Lúcia, e as duas meninas atiraram-se sobre ele com mil beijos. (p.195)

E, saindo elas pressurosamente do sepulcro, com temor e grande alegria, correram a anunciá-lo aos seus discípulos. E, indo elas a dar as novas aos seus discípulos, eis que Jesus lhes sai ao encontro, dizendo: Eu vos saúdo. E elas, chegando, abraçaram os seus pés, e o adoraram. (BÍBLIA, Evangelho de Mateus, 28, 8-9).

No dia seguinte, porém, a coisa foi muito mais solene. No grande salão de Cair Paravel - um salão formidável, com teto de marfim, uma parede coberta de penas de pavão e uma porta aberta para o mar -, na presença de todos, Aslam coroou-os com toda a cerimônia. E eles sentaram-se nos tronos, entre aclamações ensurdecedoras de "Viva o rei Pedro! Viva a rainha Susana! Viva o rei Edmundo! Viva a rainha Lúcia!” (p.218)

Ao que vencer lhe concederei que se assente comigo no meu trono; assim como eu venci, e me assentei com meu Pai no seu trono (BÍBLIA, Livro de Apocalipse, 3, 21).

E para o nosso Deus os fizeste reis e sacerdotes; e eles reinarão sobre a terra. (BÍBLIA, Livro de Apocalipse, 5, 10).

Considerando o exposto acima, podemos afirmar que C. S. Lewis construiu, por meio de "Aslam", uma metáfora da vida de Jesus Cristo de forma inovadora e surpreendente. A relação de "Aslam" com a história daquele que é chamado de filho de Deus à luz da Bíblia Sagrada torna-se inegável à medida que tal intertextualidade é passível de ser notada e se destacar, mesmo em meio a elementos de mitologias entrelaçadas.

\section{Considerações finais}

Por meio das presentes análises, notamos que C. S. Lewis escreveu uma obra que, apesar de desprovida de pretensões teológicas, deixa transparecer algumas relações com sua provável fé cristã. Assim, é criado e construído o personagem Aslan ("Aslam"), baseado em uma das imagens que o autor conhece de Deus, imagem esta que o próprio Deus permitiu que tivéssemos acesso por meio da Escritura Sagrada: o Leão. A este respeito, Magalhães Filho (2005, p.42) explica:

Na Bíblia, Cristo é retratado por várias figuras conforme a ênfase do contexto. Muitas delas parecem opor-se, como o Leão e o Cordeiro, por exemplo. Outras contrastam a fim de esclarecer que uma característica de Jesus 
não exclui a outra. Um bom exemplo disso é a menção à ira (ferocidade) do Cordeiro (símbolo da mansidão) em Apocalipse 6:16. Não é sem razão que a Bíblia fale na multiforme sabedoria de Deus.

"Aslam" é um exemplo de representação da multiforme sabedoria do Deus da Bíblia. Magalhães Filho (2005) ainda ressalta que para se ver o mundo em sua totalidade é preciso ter imaginação (p. 57); portanto, para vermos o mundo de Nárnia totalmente, precisamos mergulhar nas imagens ali projetadas, que, por sua vez, também projetam outro universo: o bíblico. Tal concepção é esclarecida pelo próprio personagem "Aslam", na crônica A viagem do Peregrino da Alvorada ${ }^{7}$ (1997), quando questionado pelo personagem "Edmundo":

- Está também em nosso mundo? - perguntou Edmundo

- Estou. Mas tenho outro nome. Têm de aprender a conhecer-me por esse nome. Foi por isso que os levei a Nárnia, para que, conhecendo-me um pouco, venham a conhecer-me melhor. (p. 230)

Ao nos dar subsídios para coletar os dados linguísticos que indicam maior frequência e concordância, a Linguística de Corpus possibilitou que observássemos a obra como um todo, bem como que nos atentássemos aos detalhes, analisando, assim, ocorrências do TF e suas respectivas traduções no TM, pontuando opções tradutórias que promoveram aproximações ou distanciamentos no que diz respeito à intertextualidade observada.

As escolhas das palavras de maior frequência favoreceram a compreensão das aproximações que tanto o autor quanto o tradutor realizaram no tocante ao contexto bíblico e às personagens cristãs, permitindo-nos, enquanto leitores, encontrar elementos semelhantes na composição do TF e do TM, e conduzindo nossa interpretação da obra.

Os patterns permitiram estabelecer as relações de sentido entre as palavras de maior frequência, mostrando-nos suas interações e promovendo a compreensão de seus sentidos dissociados e interligados pela proximidade dentro das estruturas sintáticas escolhidas no TF e no TM. Além disso, a ferramenta Concord revelou os vocábulos em contexto, favorecendo a comparação com o discurso bíblico e as construções de sentido semelhantes.

Constatamos, por fim, que a Linguística de Corpus e os Estudos da Tradução Baseados em Corpus, bem como suas ferramentas de levantamento de dados linguísticos são um importante artifício de verificação de opções léxico-semânticas e tradutórias que, por sua vez, auxiliam na análise de obras literárias. Consideramos que as palavras de maior frequência, a proximidade entre elas e as concordâncias estabelecidas apresentam fatores aos quais autores e tradutores dão maior ênfase em suas produções, podendo ser indicadores de temáticas ou reveladores de estratégias lexicais para compor subsídios para as narrativas. 
Notas

1. Por intertextualidade entendemos a criação de um texto a partir de outro préexistente. A intertextualidade pode apresentar funções diferentes, as quais dependem muito dos textos/contextos em que ela é inserida, ou seja, dependendo da situação. Exemplos de obras intertextuais incluem: alusão, conotação, versão, plágio, tradução, pastiche e paródia (ANDREWS; BERNSTEIN, 1984).

2. Mencionamos aqui o termo discurso, sem, contudo, entrarmos no mérito dos estudos provenientes da Análise do Discurso.

3. Corpus mean[s]any collection of running texts (as opposed to examples/sentences), held in electronic form and analysable automatically or semi-automatically (rather than manually).

4. "The practical question of how to improve our translations will find more reliable and realistic answers once the phenomenon of translation itself is explained in its own terms" (BAKER, 1993, p. 243).

5. Embora seja uma proposta bastante pertinente, não exploramos as questões fonéticas e fonológicas presentes na obra. No entanto, é interessante mencionar que em dados momentos a narrativa ganha ares de prece e de cânticos, lembrando uma possível relação com o costume cristão da oração ritmada.

6. Características da Divindade de Aslan.

7. Tal crônica não faz parte de nossa investigação e a utilizamos apenas para ilustrar nossa conclusão final, lembrando que todas as sete estórias de Lewis compõem um universo religioso ainda mais denso do que o explorado em nossa pesquisa.

\section{Referências}

ANDREWS, B.; BERNSTEIN, C. The language book. Southern Illinois University Press, 1984.

ARRUDA, S. M. A interface intertextual implícita entre o personagem Aslam e a pessoa de Jesus, representados, respectivamente, nas crônicas de Nárnia: o leão, a feiticeira e o guarda roupa e nos textos bíblicos. Monografia (Licenciatura em Letras) - UEPB, João Pessoa, 2016.

BAKER, M. Corpus linguistics and translation studies: Implications and applications. In: BAKER, M. et. al. Text and technology: In honour of John Sinclair, v. 233, p. 250, 1993.

Corpora in translation studies: an overview and some suggestions for future research. Target, V.7, n. 2, p. 223-243, 1995.

Linguística e estudos culturais: paradigmas complementares ou antagônicos nos estudos da Tradução? In: MARTINS, M.A.P. (Org.) Tradução e multidisciplinaridade. Rio de Janeiro: Lucena,1999, p. 15-34.

Towards a Methodology for investigation the style of literary translation. Target, Amsterdã, V. 12, n. 2, p. 241-266, 2000.

BARBOSA, M. A. Considerações sobre a Estrutura e Funções da Obra Lexicográfica : Metodologia, Tecnologia e Condições de Produção. Anais do Colóquio de Lexicologia e Lexicografia. Lisboa: Universidade Nova de Lisboa, 1990, p.229-241.

Da neologia à neologia na literatura. As ciências do léxico: lexicologia, lexicografia e terminologia. Campo Grande: UFMS, 1998. 
BERBER SARDINHA, A P. Linguística de corpus: histórico e problemática. DELTA: documentação de estudos em linguística teórica e aplicada, São Paulo, v. 16, n.2, p. 323-367, 2000.

BIBLIA SAGRADA. Edição contemporânea. Trad. João Ferreira de Almeida. Flórida: Editora Vida, 1994.

BROWN, D. Os bastidores de Nárnia. São Paulo: Editora Hagnos, 2005.

CAMARGO, D.C. Padrões de estilo de tradutores: um estudo de semelhanças e diferenças em corpora de traduções literárias, especializadas e juramentadas. 2005. 512f. Tese (Livre-Docência em Estudos da Tradução)- UNESP/IBILCE, São José do Rio Preto, 2005.

Metodologia de pesquisa em Tradução e linguística de corpus. São Paulo: Cultura Acadêmica/São José do Rio Preto: Laboratório Editorial. 2007, Coleção Brochuras, v.1.65p.

DUARTE, G. A. F. F. Uma leitura intertextual das Crônicas de Nárnia: religiosidade e diálogos com a Bíblia Sagrada. 2015. Monografia (Licenciatura em Letras) UEPB, João Pessoa, 2015.

DUBOIS, J. et al. Dicionário de linguística. Trad. Frederico Pessoa de Barros et al. São Paulo: Cultrix, 2001.

GONÇALVES, S. R. O Intertexto Bíblico na Literatura: As Crônicas de Nárnia, de C. S. Lewis. In: Anais do Congresso Internacional da Faculdades EST. 2015. p. 15041526.

GONÇALVES, L. B. Lingüística de Corpus e Análise Literária: uma Aplicação a Dubliners de Joyce. In: Anais do I Congresso Internacional da ABRAPUI, 2007, p. 1-19.

GREGGERSEN, G. Entrevista a blogueiro. 2010. Disponível em $<$ http://www.cslewis. com.br/2010/03/entrevista-a-bloggeiro/>. Acesso em: 05 jul2013.

HOLY BIBLE. King James Version. Texas: National Publishing Company, 2000.

LEITE, L. C. M. O foco narrativo.São Paulo: Ática, 1985.

LEWIS, C. S. et al. Cristianismo puro e simples. Aliança Biblica Universitária do Brasil, 1992.

. O leão, a feiticeira e o guarda-roupa. Tradução de Paulo Mendes Campos. São Paulo: Martins Fontes, 2002. 1994.

The lion, the witch and the wardrobe. New York: Harper Collins Publishers,

A viagem do peregrino da alvorada. Tradução de Paulo Mendes Campos. São Paulo: Martins Fontes, 1997.

LIRA, E. E. P. O sagrado e a intertextualidade bíblica em "As crônicas de Nárnia", de CS Lewis. Leitura: Teoria \& Prática, v. 29, n. 57, p. 51-55, 2011.

MAGAlHÃES FILHO, G. B. O imaginário em As Crônicas de Nárnia. São Paulo: Mundo Cristão, 2005.

ZYNGIER, S; VIANA, V.; JANDRE, J. (Eds.). Textos e leituras: estudos empíricos de língua e literatura. Rio de Janeiro: Publit, 2007a, 233-256.

ZYNGIER, S.; VIANA, V.; SILVEIRA, N. G. Por uma literatura de corpus: literariedade através do computador. In: Caderno de resumos do VI Encontro de Lingüística de Corpus, 2007b, 77-78. 
ZYNGIER, S. et al. Firing the canon through the computer: lexical bundles, literary genre and the translation of a best-seller. In: Anais do $4^{\circ}$ Simpósio Internacional de Estudos de Gêneros Textuais, 2007c, 354-366.

Discurso literário e linguística de corpus: uma visão empírica.Caderno de Letras (UFRJ), Rio de Janeiro, n. 28, p. 99-107, 2011.

Recebido em: 21/06/2017

Aceito em: 16/08/2017 